HStud 26 (2012)1, 123-140

DOI: 10.1556/HStud.26.2012.1.10

\title{
THE LITERARY CANON OF FERENC LISZT
}

\author{
MIHÁLY SZEGEDY-MASZÁK \\ Eötvös Loránd University \\ Budapest, Hungary
}

\begin{abstract}
Perhaps best known as a peerless virtuoso in his day and a composer the significance of whose contributions to the Western tradition was only appreciated in the latter half of the 20th century, Ferenc Liszt was also among the most ambitious composers of the 19th century in his exposure to works of literature and his interest in the interactions of literature and music. The following article examines the interrelationships between his music and the works of literature he chose as inspirations and in some cases as texts to be put to music.
\end{abstract}

Keywords: Liszt, synesthesia, interarts, Weltliteratur, tonal innovation, canon

\begin{abstract}
"die Musik kann nie und in keiner Verbindung, die sie eingeht, aufhören die höchste, die erlösende Kunst zu sein" (Wagner 1888, 191)
\end{abstract}

At the outset I would like to make two reservations. I am a lover of music, but not a musician. A literary scholar is not qualified to comment on music, so I will restrict my observations to the texts used by the composer. My other preliminary remark is more personal. In full agreement with Alan Walker's statement that "the case concerning Wagner's 'ingratitude' may have been overstated by the Lisztians" (Walker, 1997, 353), I do not wish to make any comparison between Liszt and Wagner. The harmonic experimentation of Liszt is well-known, although some experts caution against exaggerations. The author of a recent study on the late piano works, for instance, makes the following statement about the 4 . Mephisto-Walzer (Bagatelle ohne Tonart) (Mephisto Waltz No. 4 ['Bagatelle sans tonalité']: "Whether the piece succeeds in escaping the force of gravitation to a tonal centre as its subtitle indicates is doubtful" (Baker, 2005a, 117). Wagner may have drawn inspiration from Liszt's harmonic invention, but this influence cannot be analysed without considering other structural aspects of the mature works of the younger composer ("son extraordinaire capacité à construire", the role of "le contrepoint qui oriente et polarise l'harmonie", or the function of in- 
strumentation, the division of timbre in his stage works, for instance), and as such, cannot be discussed here. As Boulez reminds us, "toute influence n'est bonne que lorsqu'elle est transcendée" (Boulez, 2005, 186, 185, 586). Liszt himself was convinced that Wagner transcended his influence, as the following inscription to his piano piece Am Grabe Richard Wagners suggests:

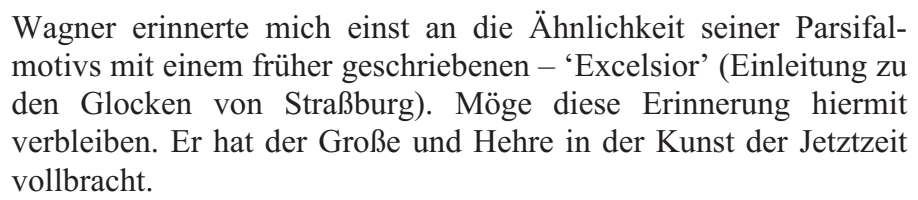

From the perspective of this essay it suffices to remark that the younger composer was also a poet, so it goes without saying that his approach to literature was different from that of his father-in-law. This is a fact of considerable significance even if it is true that in the case of Wagner there is a "décalage entre un goût littéraire passablement statique et une réflexion musicale sans cesse en marche" (Boulez, $2005,185-6,170)$.

How can a literary historian qualify the choice of poems made by Liszt? Two contradictory hypotheses merit some consideration. On the one hand, this composer accepted Goethe's idea of a Weltliteratur and sought to rely on the masterpieces of an international canon; on the other hand, it cannot be denied that some of the texts he set to music were written for minds and ears conditioned unlike ours.

In a review of a French adaptation of his Tasso in 1827, Goethe expressed his conviction that "es bilde sich eine allgemeine Weltliteratur" (Goethe, 1902-12, 38: 97). On January 31 of the same year Eckermann recorded a statement by Goethe. It clearly indicated that the poet regarded the future as a period of world literature: "National-Literatur will jetzt nicht viel sagen, die Epoche der Welt-Literatur ist an der Zeit und jeder muß jetzt dazu wirken, diese Epoche zu beschleunigen" (Eckermann, 1986, 207). In view of the fact that Liszt composed three works for male chorus (Studentenlied aus Faust 1841, Über allen Gipfeln, first version 1842, and Soldatenlied aus Faust 1845), a mixed chorus (Chor der Engel aus Faust 1849), and six songs based on texts by Goethe (Mignons Lied aus Wilhelm Meister in three versions, 1842, 1856, 1860; Es war ein König in Thule aus Faust, two versions, 1842, 1856; Der du von dem Himmel bist, four versions, 1842, c. 1856, c. 1860, and in the last days; Freudvoll und Leidvoll aus Egmont, first setting c. 1844, revised c. 1860, second setting 1848; Wer nie sein Brot mit Tränen ass aus Wilhelm Meister, two settings, c. 1845, c. 1860, Über allen Gipfeln, two versions, c. 1848, c. 1859), and ended Eine Faust Symphonie with eight lines from the second part of the poet's most celebrated tragedy, it may seem somewhat exaggerated to argue that "he did not like Goethe" (Hamburger, 2010, 190). While 
Liszt may have found the cult of the poet in Weimar embarrassing, he considered himself to be the legitimate heir to the legacy of die Weimarer Klassik, as Detlef Altenburg has convincingly argued (Altenburg, 1997, 9-32). Among his works for four hands there is a Festmarsch zur Goethejubiläumsfeier, and several pronouncements by him indicate that he viewed the authority of Goethe as almost unquestionable. When Bülow was depressed because of the unfavourable reception of the symphonic poem Die Ideale, inspired by Schiller's work, in 1859, Liszt ended his letter to his son-in-law with words attributed to the author of Faust: "Dass die Hunde bellen, beweist nur, dass wir reiten" (Liszt, 1989, 213). In 1847 he asked Karl Hugo Bernstein to find a poem by Goethe which he remembered in French translation and failed to find in the edition he owned (Liszt, 1966, 61). His correspondence is filled with quotes from the works of this German poet (Liszt, 1989, 189, 232). "Dante's Commedia and Goethe's Faust lead us to the same celestrial height", he told August Stradal (Szabolcsi, 1956, 10). In 1837 Marie d'Agoult and Liszt "read Dante together", and later, "on alternate days, Dante, Shakespeare, Goethe and Tasso" (Walker, 1970, 5). The German poet's advocacy of Weltliteratur may have inspired Liszt to draw upon poetry in different languages. At the same time, his experience with poetic texts may have convinced him that music was more international than literature. It is even possible that Goethe's passion for the visual arts set an example for him. In this context it should not be forgotten that sometimes he turned to images accompanied with texts. Holbein's series of woodcuts, Der Totentanz, for instance, is combined with quatrains.

Of course, it could be argued that the Romantics drew interart parallels less cautiously than we may be inclined to do. "Le sentiment et la réflexion me pénetraient chaque jour davantage de la relation cachée qui unit les oeuvres de génie. [...] Dante a trouvé son expression pittoresque dans Orcagna et Michel-Ange; il trouvera peut-être un jour son expression musicale dans le Beethoven de l'avenir." This declaration made in a letter addressed to Berlioz and published in the La Gazette musicale on 24 October 1839 suggests that the composer ascribed great significance to the "correspondances entre ses oeuvres et celles qui les ont inspirées" (Le Diagon-Jacquin, 2009, 27, 29).

It has long been known that first-rate music is often inspired by bad literature and vice versa. As a literary scholar I cannot accept the assumption according to which "the settings of worthless poems [are] on the whole worthless and the settings of the fine poems [are] fine music" (Cooper, 1938, 173). The literary value of Elim Metscheresky's Bist du! is negligible, but the second setting of this poem by Liszt is of considerable interest on account of its use of an augmented triad (Arnold, 2002, 409). Similar contradictions can be found in works by other composers. The texts of Winterreise are undoubtedly inferior to the music and the opera by Thomas is hardly comparable to Shakespeare's Hamlet. There were few com- 
posers whose literary taste could be called outstanding. Kodály was a fine reader of Hungarian verse, most of Elliott Carter's and Britten's texts are all first-rate works of art, and Boulez is a highly sophisticated interpreter of such poets of great originality as Mallarmé, Henri Michaux, and René Char. One should be under no illusions as to the difficulty of an interdisciplinary approach to arts as different as music and literature or music and the visual arts. Just as mediocre verse was often transformed into great music and vice versa, in a similar way, second-rate paintings frequently inspired wonderful music. Today the St. Francis of Paola of Eduard Jakob Steinle (1810-86) is remembered chiefly because it inspired the second legend, Saint François de Paule marchant sur les flots. The same may apply to Kaulbach's Hunnenschlacht, exemplifying the sort of history painting condemned by Senancour, one of Liszt's favourite authors. Very few major composers could appreciate works by their best contemporaries in the sister arts. Nowadays we might be inclined to avoid the word extraartistic, but that does not mean we should exclude the possibility that the composer cherished Steinle's painting because St. Francis of Paola was his patron saint. Similarly subjective causes might have urged him to set certain poems to music. One of the recitations with piano, A holt költó szerelme (The Dead Poet's Love) was ridiculed a few days after its first performance on 16 March 1874 (Somssich, 1925, 372). The author of the text was Mór Jókai, an important novelist but a negligible verse writer. Liszt must have composed this work for the simple reason that he was on friendly terms with Jókai.

The literary canon of Liszt is uneven from the perspective of the present day. Let me emphasize the importance of the second half of this sentence. Rückert was seen as a worthy poet even by Mahler and the young Alban Berg. Some of the poems Liszt set to music have lost their expressive power. We should not forget that literary canons are as changeable as musical repertoires. It is quite possible that the composer could distinguish second-rate works from masterpieces, just as he regarded a sculpture by Canova as "détestablement médiocre" and the "tombeau de pape à Saint-Pierre" by Thorwaldsen as "froid et bien guindé", in comparison with works by Michelangelo (Le Diagon-Jacquin, 2009, 80). As an American scholar remarked in a recent collection of essays, "Liszt draws at times on the greatest of German poets, such as Goethe and Schiller, to lesser-known writers, such as Georg Herwegh (1817-75), and even pedestrian authors of third-rate verses" (Wendland, 2002, 370). Not all musicologists may realize that unlike such versifiers as Ludwig Rellstab (1799-1860), Josef Müller (1802-72), or Charlotte von Hagn (1809-91), most of Liszt's contemporaries whose texts he set to music, for example August Heinrich Hoffmann von Fallersleben (1798-1874), Ferdinand Freiligrath (1810-76), Friedrich Martin Bodenstedt (1813-92), Emanuel Geibel (1815-84), or Oskar von Redwitz (1823-91), are still regarded by literary historians as minor poets of some significance. Poems not only by 
Hebbel but also by these authors are included in the ten-volume Epochen der deutschen Lyrik, a widely respected collection published in the second half of the 20th century (Wuthenow, 1970). One of the texts by Herwegh was used by the composer for a work for men's voices. Der Gang um Mitternacht, probably composed around 1845, is a document of political radicalism rather than a literary work of art. More important is the poem starting with the words Ich möchte hingehn. It has been suggested that Liszt inserted a short citation from Tristan in the second version of his song, following the words "Du wirst nicht stille wie der Stern versinken" (Rehding, 2000). Be as it may, I would call the use of this poem justifiable from a literary perspective. Although Herwegh's political verse is dated, his interest in Schopenhauer and Hölderlin is palpable in some of his poems.

The verse of Bürger, Uhland, Rückert, or Béranger was heard differently in the 19th century. The same might be said even of Lamartine. The editor of his OEuvres poétiques, published in 1963, started his preface with the admission: "peu le lisent et personne ne l'aime plus". "Ne cherchons pas ailleurs la [...] raison du prodigieux succès des Médiations : les lecteurs ouvraient un livre dont l'auteur ne bouleversait aucune de leurs habitudes de langage ou de rhétorique" (Lamartine 1963, ix, xv). If we accept that the symphonic poem known as Les préludes was "ostensibly modeled in its instrumental form on a poem by Lamartine" (Saffle, 2002, 247), we have to remember that Les préludes was published with a program drafted by Bülow, a prose paraphrase of the sixteenth piece of Nouvelles Méditations, first published in 1823. Lamartine's poem Les préludes is a loose conglomeration of segments of varyig length and form. It contains numerous references to music, starting with the following words in the first segment:

[...] O lyre! Ô mon génie!

Musique intérieure, ineffable harmonie,

Harpes, que j'entendais résonner dans les airs

Comme un écho lointain des célestes concerts.

The program statement by Bülow is incomparably shorter than the French poem. In contrast to Lamartine's text, it has a clear-cut structure. One can go even further and see a contradiction between the French poem and Bülow's text. As Richard Taruskin remarks, "the program's all-important motivating Question nowhere occurs in Lamartine's poem" (Taruskin, 2005, 3: 425). In any case, Liszt may not have realized that Lamartine's diction, his rhetorical syntax and use of dead metaphors represented the legacy of the 18th century, a period not known for the excellence of lyrics in French.

Without much exaggeration, it could be added that even Hugo's reputation declined in the 20th century. "Hugo est un intense et grouillant moment de la culture en éventail du XIXe siècle, non une marche effective de la connaissance poétique 
de ce siècle", one of the major poets of the 20th century observed in 1952. René Char's cruel assessment of Hugo's rhetoric is far from being idiosyncratic; it reflects a widespread distrust of moralizing inspired by an unqualified confidence in social progress. "À notre époque, voici le poète le moins indispensable qui soit [...]. Il a des thèmes pour tous les âges et pour tous les idéaux, mais nul de ces thèmes n'est safisfaisant pour aucun" (Brunel, 2007, 112).

The main strength of Liszt's approach to literature is an internationalism that is almost unparalleled in the history of music. As is well-known, he succeeded in assimilating components of Italian, French, German, and Hungarian music. "Liszt, en effet, n'a jamais possédé de domicile permanent, [...] il est demeuré toujours celui que Berlioz avait surnommé 'l'infatigable vagabond", as one of his biographers remarked (Bory, 1936, 12). There seems to be a consensus among musicologists that his best language was French. On 29 December 1839 and on 9 January of the next year, at receptions held in the National Casino of Pest, he addressed the Hungarians in French (Somssich, 1925, 129, 137, 140), and he used the same language in the speech he made in the Hungarian Theatre of Pest on January 4th (Walker, 1983, 325-6). Wagner in his autobiography refers to Liszt as speaking French when they met for the first time in 1840:

\footnotetext{
Unfähig, an der französichen Konversation, welche sich um die Erlebnisse Liszts während seiner letzten Kunstreise in Ungarn bewegte, teilzunehmen, hörte ich eine Zeitlang aufrichtig gelangweilt zu, bis ich endlich von Liszt freundlich gefragt wurde, womit er mir dienen könne (Wagner, 1976, 251).
}

In his youth he became familiar with numerous French Romantics, for which Marie d'Agoult may take much of the credit. The couple met Senancour, Sainte-Beuve, Lamartine, Vigny, Hugo, and Lamennais, among others. In light of this, it is somewhat surprising that Liszt wrote in German to Barabás, who painted his portrait in 1846, although he must have known that the Hungarian artist preferred to communicate in French, the native language of his wife.

At any rate, it is safe to assume that Liszt read mainly in French and German. Among his songs some 168 are based on German poems (not including five melodramas or recitations) and only 12 on French texts. Mistakes in the setting of language prove that he had a more limited command of other languages. In the first version of Petrarca's sonnet "I vidi in terra angelici costumi", the word "soglia" "is set as three syllables", and in the Hungarian song Isten veled (composed in 1846-47) the stress is placed on the second syllable of the word "szerelmed" (Walker, 1970, 226).

Vocal music must conform to the natural rhythm of the language. In purely instrumental music it may be much more difficult to find objective criteria for an analysis of the impact of a text. In great works of art sources of inspiration are hard 
to detect; they seem to disappear during the creative process. "Le compositeur, par sa démarche vers l'accomplissement de l'oeuvre, détruit lui-même ses sources. Elles restent son secret. On peut défricher les alentours de ce secret, on ne peut jamais le découvrir" (Boulez, 2005, 254). Because of my professional bias, I am scared of the literary interpretations of instrumental music. I am not sure I could prove that in the first piece of the cycle entitled Harmonies poétiques et religieuses a certain "passage de transition met en musique les vers 4-7 du poème de Lamartine "Invocation"” (Grabócz, 1986, 103). To what extent does it matter that Der Tanz in der Dorfschenke (composed in 1877 and known as the First Mephisto Waltz) was inspired by Lenau and not by Goethe? In what sense does it further an understanding of Prométhée (as it appears on the title page of the edition of Symphonische Dichtungen für grosses Orchester published by Breitkopf und Härtel) to know that it was originally composed as an overture to Herder's Der entfesselte Prometheus and not to some other work about the mythological figure? The programs published as frontispieces to the scores of Liszt's symphonic poems were written after the music was composed, and "there is evidence that Princess Carolyne had a hand in their formulation", so Alan Walker's conclusion is worth remembering: "Posterity may have overestimated the importance of extra-musical thought in Liszt's symphonic poems" (Walker, 1989, 307). Let me refer to Mahler, who decided to drop the program he had drafted for his Third symphony. I am almost tempted to believe that sources of inspiration and programs may be more relevant for the analysis of the creative process than for the interpretation of the finished work of art. It is quite possible that the "Entfaltungsform" of some of Liszt's piano pieces evolved "sous l'influence de la littérature contemporaine" (Grabócz, 2009, 232) but such sources may not be of great significance for the interpretation of these works.

What attracted Liszt to Obermann, or rather what role can be ascribed to it in any interpretation of piece 4 of the series originally called Album d'un voyageur, composed in 1835-36? Senancour's confessional work is so loose and fragmentary that it would be hard to seek any structural comparison with Liszt's piano piece. The epistolary framework is almost a mere formality, since the addressed "mon ami" has no specific characteristics. As Obermann himself admits, his letters "ressemblent beacoup trop à traités" (Senancour, 1999, 278). "Là, l'homme retrouve sa forme altérable, mais indestructible; il respire l'air sauvage loin des émanations sociales; son être est à lui comme à l'univers: il vit d'une vie réelle dans l'unité sublime" (Senancour, 1999, 95). Although the characterizations of the sense of being associated by Obermann with living in the high Alps may have inspired the composer, the title of the piano piece refers to a place seen in dreams. First the valley seems to have a beauty that cannot exist in ordinary experience, but in a second dream it is transformed into a demonic vision: 
Il y a plusieurs semaines que j'ai vu une vallée délicieuse, si parfaitement disposée selon mes goûts, que je doute qu'il en existe de semblables. La nuit dernière je l'ai vue encore, et j'y ai trouvé de plus un vieillard, tout seul, qui mangeait de mauvais pain à la porte d'une petite cabale fort misérable (Senancour, 1999, 431).

As the dream continues, Obermann finds himself in a boat that sinks.

On a more abstract level, Senancour's belief that vision can be transformed into music, the Romantic ideal of the interrelations of the arts, probably related to the concepts of program music and Gesamtkunstwerk, may have appealed to Liszt. Obermann contains meditations on the possibility of intermedial translation. His hypotheses on landscape transformed into music could not have escaped the attention of the composer. Senancour, who in 1811 published an article in the Mercure de France entitled "Du style dans les descriptions", rephrased the ideas of the "querelle des anciens et des modernes". Relying on certain passages in the works of Jean-Jacques Rousseau, taking a description of dawn in Book 3 of Émile as a model, he opposed "les peintres d'histoire" to "la peinture des objects inanimés" (Senancour, 1999, 505, 503).

To avoid any simplification, it needs to be admitted that Senancour regarded the text as part of vocal music, but only as "un moyen secondaire de l'expression". It is more than likely that Liszt remembered that in the thirty-fifth letter the author of Obermann insists that music is independent of text. Taking the words "J'ai perdu mon Eurydice" as an example, he argues in the following manner:

Quand vous substituez le mot trouvé au mot perdu, vous mettez la joie à la place de la douleur, vous conservez les mêmes notes; mais vous changez absolument les moyens secondaires de l'expression. Il est incontestable [...] que la note est arbitraire (Senancour, 1999, 158).

Like Senancour, Liszt looked at nature under the influence of Jean-Jacques Rousseau. In his letter addressed to George Sand, published on 12 February 1836, he spoke about forms created by "l'imagination du promeneur solitaire" (Le Diagon-Jacquin, 2009, 54). Arguing that "la contemplation de la nature a quelque chose de sévère", Senancour focused on the materiality of description. His chef-d'oeuvre is not a novel or even a romance because it dispenses with story telling. "Ces lettres ne sont pas un roman" (Senancour, 1999, 52). These words in the introductory "Observations" warn the reader that s/he should not expect a narrative. Letter LX explicitly states that a story of adventures and the introduction of characters have not place in Obermann's confessions: "Un solitaire ne vous parlera point des hommes que vous fréquentez plus que lui. Il n'aura pas d'aventures, il ne vous fera pas le roman de sa vie" (Senancour, 1999, 306). 
By insisting on the specificity of the medium, Senancour warned against the temptation of discovering a common deep structure in the different arts, against the belief that "tout motif est susceptible de se retrouver aussi bien sous la forme verbale que non verbale, qu'il reste indépendant du signifiant utilisé, de type linguistique comme non linguistique, peu importe", to quote from Daniel Russo's preface to a recent study on Liszt (Le Diagon-Jacquin, 2009, 24). In Obermann materiality also implies "la couleur locale", which in Senancour's view is the distinguishing feature of the "romantic". As he argues, "le rossignol chante sur les rives de Tanais [...] sur un ton différent" (Senancour, 1999, 506), and such specificities are highlighted in Obermann.

One may also try to seek a more "philosophical" explanation for the title Vallée d'Obermann. The writing self of Senancour's letters is filled with high ambitions. "Je sais que plusieurs trouvent assez de permanence dans un bien du moment, et que d'autres savent se borner à une manière d'être sans ordre et sans goût." Senancour's chef-d'oeuvre is marked by a dissatisfaction with the attitude towards life professed by his contemporaries, with what he calls "une existence ridicule" (Senancour, 1999, 125). Obermann looks down upon the life of the "petits bourgeois de certaines villes", who are imprisoned in their local habits, "tout enveloppés de leurs habitudes" (Senancour 1999, 373). The contempt Senancour, E. T. A. Hoffmann, Robert Schumann, Richard Wagner, and other Romantics felt for Spießbürgerlichkeit was not foreign to Liszt. According to the composer of Tannhäuser, after a rehearsal of that work, in 1849, Liszt became so angry with the petty and narrow-minded members of Weimar society that he had to recover from an attack of nerves ("Nervenanfall") (Wagner, 1976, 426). On 2 May 1855, he complained to Wagner that the philistinism of the English public was just as bad as that of the Germans (Liszt, 1989, 176). What may have attracted him to Obermann was Senancour's vision of the sublime, which the French author defined, possibly under the influence of Burke and Kant, as the most sophisticated of three kinds of aesthetic value: "Le joli amuse la pensée, le beau soutient l'âme, le sublime l'étonne ou l'exalte". Vallée d'Obermann may be regarded as an attempt to express what Senancour described as qualities "peu connues, jamais expliqées, mystérieuses et ineffables". The emphasis is on the last adjective. In the next paragraph it is suggested that the sublime needs to be interpreted in terms of "harmonies" rather than in verbal form (Senancour, 1999, 133).

Just as writers often tend to talk around music, composers or musicologists sometimes refer to a source of inspiration without obvious justification. A case in point is Les préludes. As is well-known, this symphonic poem had several antecedents. One of them was a choral work entitled Les quatre éléments, to words by Joseph Autran. The hypothesis that Liszt decided to replace the name of this poet with that of the far better-known Lamartine for publicity reasons is probably not without foundation. A somewhat different case is that of the piano study 
Mazeppa, which in its first version, composed in 1838, bore no title. Later the ending was altered to fit the story of the Polish nobleman as related by Voltaire in Charles XII. In short, it is not incorrect to assume that "the music came first and it was later altered to fit the story" (Walker, 1970, 293).

Of course, regarding the contention according to which the symphonic poem Hamlet is "a character sketch (Walker, 1970, 298) or a dual character portrait of the melancholy prince and his doomed lover" (Saffle, 2002, 258), it should not be forgotten that in the 19th century most people, and especially those who read the text or saw a performance of the play in a language other than English, were interested in the psyche of the Prince of Denmark rather than in the play as a whole. In an age dominated by novels written by character-mongers such as Balzac, Dickens, or Trollope, textuality was out of fashion. The title of Eine Faust-Symphonie in drei Charakterbildern (nach Goethe) may remind us that the textual approach to literary works characterizing such 20th-century trends as Russian Formalism, Anglo-American New Criticism, or French Structuralism was a far cry from the character-oriented method predominant in the 19th century. In 1838 a long article entitled "The Recital of Ferenc Liszt in Milan" appeared in the Hungarian journal Társalkodó. Thalberg was compared to Goethe, whereas Liszt to the author of Childe Harold's Pilgrimage. A reader familiar with textual poetics would be reluctant to speak of such similarities.

On 2 October 2011 Nike Wagner gave a "Vortrag" in the main hall of the Hungarian Academy of Sciences. She presented Liszt as a European "voyageur" who was "kein Dogmatiker und kein Purist", and highlighted "seine musikalische Assimilationsfähigkeit". It should not be forgotten that in instrumental music it might be easier to think in terms of a Weltiteratur. Vocal music represents a somewhat different case. In songs or choral works the composer cannot ignore the text. He/she has to come to terms with it on some level. In 1861 Bülow asked Liszt to make changes in the Chorus Mysticus of Eine Faust Symphonie to make it conform to the natural rhythm of the German language. I would take the contention according to which "his ideal was and continued to be Byron" (Hamburger, 2010, 190 ) with some caution. Byron is certainly less difficult to read than Shakespeare, whose works Liszt may have read in French, as his letter of 28 June 1835 suggests (Liszt, 1989, 39). It is best to bear in mind that uneven as his command of German may have been, he could read Goethe in the original, whereas his English was probably not good enough to read Byron in the same way. He mentions in his letter to Marie d'Agoult, written on January 25-26, 1842 that Adolf Böttger had sent him Lord Byron's Sämmtliche Werke (Leipzig, 1839) (Liszt, 1989, 71-2), so he may have known the works of this poet in translation. He set only one English text to music, late in his career, in 1879. Alan Walker calls the song based on Tennyson's Go not happy day (section XVII of the monodrama Maud) "rather disappointing" (Walker, 1970, 239). Although Liszt mentions not only Goethe's play 
but also Byron's The Lament of Tasso, and the opening Lento of the symphonic poem is a Lamento, it is probably safe to assume that he had a better understanding of the German text. Far be it from me to deny that the international cult of Byron appealed to him - three of the pieces in the first volume of Années de Pélèrinage (Au lac de Wallenstadt, Orage, and Églogue) were published with mottos from Childe Harold's Pilgrimage - but I would caution against placing too much emphasis on the influence of Byron's verse. It is probably no exaggeration to say that at least in one case Liszt approached Byron's work indirectly. Hugo's poem Mazeppa, written in 1828, has an inscription from Byron's tale that is a mere repetition of one word (“Away! - Away! -"). The piano piece Liszt composed in 1840 is dedicated to Hugo, so it seems likely that he approached Byron's narrative through Les Orientales.

Some could argue that the choice of verse was sometimes made by others for the composer, but I cannot imagine any reader who would be entirely independent of the influence of others. Alan Walker reminds us that it was "Carolyne's suggestion that Liszt should consider setting some of Longfellow's verse. At Liszt's request, she provided him with a German translation of the famous poem The Golden Legend" (Walker, 1997, 168). Part one of the cantata Die Glocken des Straßburger Münsters is based on the poem Excelsior. This text "used to be required reading for every American schoolchild", wrote Alan Walker. "But that was in yesterday's more literate world", he added (Walker, 1997, 281). With all my respect for an outstanding musicologist, I cannot help remarking that in the 20th century the reputation of Longfellow was questioned by the American New Critics. Excelsior was dismissed by Louis Untermeyer (1885-1977), the Jewish American poet who in 1933 published a representative anthology of English and American verse for The Albatross Verlag, by Cleanth Brooks and Robert Penn Warren, two major New Critics, whose Understanding Poetry, first published in 1938, became one of the most influential textbooks of the 20th century, by the illustrious American scholar F. O. Mathiessen, whose very generous selection The Oxford Book of American Verse, first published in 1950, was reprinted numerous times, and by the poet Oscar Williams, the editor of The New Pocket Anthology of American Verse, a book first published in 1955 that went into several editions in the second half of the century. "His reputation, so high in his own day, suffered a severe reverse, from which it has never recovered", as an encyclopedia of poetics says (Spender - Hall, 1963, 191). The lustre of Longfellow's verse seems diminished today. Few of his works are remembered and The Golden Legend is certainly not one of them. The translation is amateurish. That does not detract from the value of the twenty-minute cantata, composed in 1874. It can happen that poems of similar quality by the same author inspire the same composer to create relatively conventional and highly experimental works. The popular song Die drei Zigeuner, with ornamentation and rhythmical patterns reminiscent of the earlier 
rhapsodies, and the melodrama Der traurige Mönch, with accompaniment marked by the use of the whole-tone scale and the augmented triad, can be cited as examples. His letter to the excellent singer Emilie Genast, dating from 1860, indicates that in the melodrama the composer deliberately resorted to what he called "atonal dissonances" (Liszt, 1989, 232).

Sometimes Liszt is called a polyglot. His cosmopolitanism had one disadvantage; he had no native language in the strict sense of the word. In a letter written to Eduard Liszt on 17 December 1837, the composer praised the youngest son of his grandfather for his decision to learn French, arguing that all should do so unless "they wish to be buried for good in their village" (Liszt, 1989, 48). He may have been influenced by the linguistic universalism of the Enlightenment that started with Descartes and culminated in the debates of the revolutionary Convention during which Bertrand Barère (1755-1841) associated multilingalism with feudalism and superstition and Henri Grégoire (1750-1831) drafted a Rapport sur les nécessités et les moyens d'anéantir les patois et d'universaliser l'usage de la langue française (Ost, 2009, 303-9). In the same letter he confessed that he was afraid of losing his German. It is quite possible that French gave him that little fillup which we get from using a language whose edges have been smoothed by daily use. At any rate, it seems that at certain stages of his life, particularly before the Weimar years, his command of French may have been superior to his German. Alan Walker goes even further by insisting that "Many of the essays that appeared over Liszt's signature in the 1850s (on Wagner, Schumann, Chopin, and others) were translated by [Peter] Cornelius from French into German" (Walker, 1989, 194). Still French was not his mother tongue. "You may find a lot of shortcomings in my French", he wrote to Marie d'Agoult on 6 January 1840, and a letter of 30 October 1842 suggests that she reproached him for not respecting French grammar (Liszt, 1989, 63, 79). It is possible that the Lettres d'un bachelier, a series insisting on the fusion of the arts, is "the work of d'Agoult, rather than Liszt" (Ellis, 2005,3 ). Whether it is true that "most of his prose works seem to have been ghost-written by, or at least dictated to, whoever was his girlfriend at the time" (Rehding, 2005, 16), it is undeniable that in some cases he expected his mistress to be his co-author. On 22 February 1837, for instance, he asked her to prepare an article which he meant to publish under his name. Although he gave detailed instructions to her, he expected her to elaborate on the topics he suggested (Liszt, 1989, 43-4). As is well-known, in the Weimar years Liszt dictated much of his writing to Carolyne von Sayn-Wittgenstein. Alan Walker regards the composer's authorship of the numerous articles written in this period as beyond dispute by arguing that "Churchill, Napoleon, Kossuth, Marco Polo, and Henry James all liked to dictate their prose [...]. No one, to our knowledge, has disputed the authorship of their prose" (Walker, 1989, 376). At least one of these comparisons may seem less than convincing if one remembers that James engaged a stenographer only in 
his late phase, after "his wrist condition became chronic" during the winter of 1896-97 (Edel, 1977, 2: 230).

In 1824 in his letter to Pierre Erard Liszt used English words (Bory, 1936, 53), he communicated with Miklós Wesselényi and Richard Wagner partly in French and partly in German, and occasionally started a sentence in English and continued in French even when adressing Marie d'Agoult (Liszt, 1989, 40). In general, he frequently mixed French and German, sometimes even within one sentence. He was not the product of French civilization and may have felt somewhat ill at ease for all his magnificent urbanity in Parisian culture, despite the fact that he was admired as "l'un des lions authentiques de la société" in the French capital, "beau comme un dieu et traînant tous les coeurs après soi", to quote Alfred Cortot (Bory, 1936, 19). While the popularity of the young Liszt was unquestionably high among women, "le rêve d'une femme serait d'avoir Chopin pour mari, Hiller pour ami et Liszt pour amant", said one of them, it would be somewhat misleading to believe that he was at home in French society as a whole. "Une grande confusion semble régner dans la mentalité de ce jeune homme." That declaration by the historian François Mignet (1776-1884) may exemplify the ambiguity in the attitude of the intellectuals of Paris towards the young Liszt (Bory, 1936, 23). From a national perspective a supranationalist may seem to belong to some other community. Chopin's words about Liszt the composer: "his works will be buried forever in souvenir albums, together with volumes and volumes of German poetry" (Walker, 1970, 80) suggest that in Paris some regarded Liszt as German. In his later years he himself may have distanced himself from French culture. In 1870, after a concert of his music in Leipzig, when Olga Janina tried to speak French, the composer interrupted her by saying "We do not speak French here!" (Walker, 1996, 210).

In conclusion, speaking about the relationship between text and music, four types could be distinguished. The difference between vocal and instrumental music allegedly inspired by literary works is clear-cut. A third type is constituted by scores headed by a text. A literary scholar may be tempted to investigate the relationships between the verbal utterance and the music in such cases as Au bord d'une source, which is headed by words by Schiller, or Il Penseroso, which bears a motto by Michelangelo. The earliest of the symphonic poems, Ce qu'on entend sur la montagne, is prefaced by the poem from Victor Hugo's Feuillets d'automne. In the first edition Liszt even added a short foreword in which he gave his interpretation of the text, emphasizing that the lyric self listens to two conflicting voices, one of them praising, the other cursing the Lord. In other words, the music is preceded by a verbal interpretation that serves two purposes: it is meant to be a key to both a poetic and a musical composition. The reader-listener should not necessarily accept the composer's interpretation. It seems obvious that Liszt may have failed to realize that the end of the poem questions teleology: 
Et je me demandai pourquoi l'on est ici, Quel peut être après tout le but de tout ceci,

Passages from Schiller's Die Ideale are quoted at various places in the score of the symphonic poem by that title. A superficial approach would suggest that in this case the textual fragments play the role of a running commentary on the musical process. Such an interpretation, however, is somewhat misleading, for the extracts do not follow in the original order. Having selected certain passages, the composer rearranged them, subordinating text to music.

The third piece in the series Harmonies poétiques et religieuses, prefaced by lines by Lamartine, might be a special case provided one accepts the interpretation based on the idea that the opening melody in the left hand has been "moulded to fit the words of Lamartine's poem" (Walker, 1970, 129). If this is so, Bénédiction de Dieu dans la solitude anticipates the technique used in Eine Symphonie zu Dantes Divina Commedia. In the Inferno movement textual fragments are turned into musical themes. The Italian text is written above the notes in the Canzonetta del Salvator Rosa, suggesting an arrangement of the marching song by the Italian painter. This structural device marks a transition to the three Petrarca sonnets of the Années de Pèlerinage, which represent a fourth type that could be called instrumental transcription of vocal music.

It is a misconception to believe that any work can be transcribed "faithfully" from one medium to another, not deviating from the so-called original. In the same way as a literary translation involves an imaginative re-thinking, re-casting, or re-creation of the source text into a target text, vocal music cannot be transformed into instrumental music without fundamental changes, additions and losses. It has been pointed out that the basic element of the piano piece Sonnet No. 47 ("Benedetto sia'l giorno") is "syncopation", "not to be found in the song" (Walker, 1970, 123). The fourth, fifth, and sixth pieces of the Deuxième Année are works radically different from the three Petrarca songs.

The works of Carl Dahlhaus prove that musicologists can profit from literary hermeneutics. Literary scholars seem to be more reluctant to learn from interart studies. The reason for this is not only specialization but also the huge quantity of primary and secondary texts a literary historian is expected to read. From the perspective of literary studies it is misleading to assume that vocal music should do justice to the text.

When a composer puts a poem to music, he annihilates the poem and makes a song. [...] A poem that has perfect form, in which everything is said and nothing merely adumbrated, a work completely developed and closed, does not readily lend itself to composition. It will not give up its literary form. This is true of most of Goethe's poems (Langer, 1953, 153-4). 
If this argument, made by an American philosopher well-versed in close reading, holds, the objection that Liszt modified the text of Der $d u$ von dem Himmel bist "arbitrarily" (Hamburger, 2010, 452) is not entirely relevant. Bartók also made alterations in Ady's poems when he composed his opus 16. Numerous other cases could be cited. Being a literary historian, I can probably afford to insist that the text is rarely a useful starting point for the musical analysis of instrumental works. Moreover, the temptation to regard a song as a kind of "addition" to the text or even a "heightening" of its tension may lead to the underrating of the autonomy of musical composition. In recent decades translation and media studies developed as separate disciplines. Source-oriented approaches have been replaced by target-oriented analyses. Setting texts to music is intermedial translation. The medium is the message. The text has to be deconstructed by the composer. That is why I would not point out elements that are "alien to the text" or "incompatible with the poem". The experience of Pierre Boulez may give some authority to his statement that "the poème possède et garde son autonomie: il existe avec la musique, mais il demeure indépendant du son auquel le compositeur l'a lié" (Boulez, 2005, 710-11). The function of vocal music is not literary interpretation. A composer's task is not to respect the integrity of the literary work of art, or identify himself with what the poem says. If we speak of the abuse of the text, we ignore the mode of existence of the musical composition.

The message of the poem is never given, it has to be decoded by a reader. The interpretation of a piece of music, vocal or instrumental, is a different activity. We can do justice to the art of Liszt only if we accept this fundamental principle. As Susan K. Langer warned almost sixty years ago:

\footnotetext{
What all good composers do with language is neither to ignore its character nor to obey poetic laws, but to transform the entire verbal material - sound, meaning, and all - into musical elements. When words enter into music they are no longer prose or poetry, they are elements of the music (Langer, 1953, 150).
}

In a lecture entitled "Dire, jouer, chanter", given in Basel in 1962, Boulez gave a similar, although somewhat more nuanced characterization of the status of text in vocal music:

\footnotetext{
le poème est centre de la musique, mais il est devenu absent de la musique, telle la forme d'un objet restituée par la lave, alors que l'objet lui-même a disparu - telle encore, la pétrification d'un objet à la fois REconnaissable et MÉconnaissable (Boulez, 2005, 87).
}

The textual canon of most, if not all composers is questionable from the point of view of the literary scholar, but such a perspective may be almost irrelevant for the simple reason that the poetic value of a text disappears in the moment a com- 
poser decides to use that text for his/her own purposes. Inspiration cannot be ignored, but the aesthetic quality of music does not depend on the artistic merits of the poem used by the composer. Literary critics may learn an important lesson from the works of Liszt. Alan Walker's warning that those who believe that his compositions progress towards a "final" form "misunderstand Liszt's art" (Walker, 1983, 306) is legitimate. As is well-known, even his paraphrase of Isolde's "Liebestod" has three versions. In some cases it is not easy to decide whether what we have are two versions or two individual works. La Notte (1866) starts as a second version of the much shorter Il Penseroso (1838-39), but continues with a passage containing "Hungarian" characteristics that are absent from the earlier piece. Many of Liszt's compositions suggest that the ideal of the finished work of art is a questionable concept. One critic goes even as far as suggesting that "in many cases throughout his career it seems as if Liszt's compositional concepts were not wedded to a particular medium" (Baker, 2005b, 120). At any rate, it is not always easy to prefer one version to the other. In the second versions of Benedetto sia'l giorno and Pace non trovo Liszt employs whole-tone chords, but "he reduces the melodic variety, waters down the previously brilliant pianism, and removes much of the torrid passion that made the first versions so wonderful", as one critic admits (Arnold, 2002, 416). I would agree with those who believe that the Eroica étude is a work "where there is an arguable case for preferring the 1837 study above that of 1851" (Hamilton, 2005, 74).

Recently the argument was put forward that the decline in the esteem for Liszt as composer had been caused by the "aesthetic of form", whereas from the late 20 th century his reputation was restored "under the aspects of postmodern culture" (Le Diagon-Jacquin, 2009, 15). I have only one reservation about this argument. The expression "aesthetic of form" reminds me of the duality of content and form, a distinction rejected as early as 1931 by Roman Ingarden, in his seminal work Das literarische Kunstwerk. Instead of relying on a dated distinction, let me quote Bartók: "neither in earlier periods nor in his age did any other major composer expose himself to so radically different, even incompatible influences" (Bartók, 1936, 4). "Liszt created an art form which our time necessarily regards as a mistake, while a later time will perhaps again see exclusively the genius' insight on which it is based." This prophecy made by Schönberg in 1911 (Schoenberg, 1984,443 ) has come true. Our age is tolerant of contradictions in style, a characteristic feature of the works of Liszt, a composer whose activity represents a wide range of solutions to the old problem: how can music integrate literary works. He wished to "reform music through an intimate alliance with poetry", as he himself said in 1860 (Liszt, 1989, 234). In his best works he may have achieved this goal. 


\section{References}

Altenburg, Detlef (Hrsg.) (1997) Liszt und die Weimarer Klassik (Laaber: Laaber).

Baker, James M. (2005a) 'Liszt's late piano works: A survey' in Kenneth Hamilton (ed.) The Cambridge Companion to Liszt (Cambridge: Cambridge University Press), 86-119.

Baker, James M. (2005b) 'Liszt's late piano works: larger forms', in Kenneth Hamilton (ed.) The Cambridge Companion to Liszt (Cambridge: Cambridge University Press), 120-51.

Bory, Robert (1936) La vie de Franz Liszt par l'image. Précédée d'une introduction biographique par Alfred Cortot (Genève: Alexande Jullien).

Boulez, Pierre (2005) Regards sur autrui (Points de repère, tome II). Textes réunis et présentés par Jean-Jacques Nattiez et Sophie Galaise (Paris: Christian Bourgois).

Brunel, Pierre (2207) Baudelaire antique et moderne (Presses de l'Université Paris - Sorbonne).

Cooper, Martin (1938) 'Liszt as a Song Writer' Music \& Letters Vol. 19, 171-81.

Eckermann, Johann Peter (1986) Gespräche mit Goethe in den letzten Jahren seines Lebens. Herausgegeben von Heinz Schlaffer (München - Wien: Carl Hanser).

Edel, Leon (1977) The Life of Henry James (Harmondsworth, Middlesex: Penguin).

Ellis, Katherine (2005) 'Liszt: the Romantic artist' in Kenneth Hamilton (ed.) The Cambridge Companion to Liszt (Cambridge: Cambridge University Press), 1-13.

Goethe, Johann Wolfgang von (1902-12) Sämtliche Werke. Jubiläums-Ausgabe. Herausgegeben von Eduard von der Hellen (Suttgart: Cotta).

Grabócz, Márta (1986) Morphologie des oeuvres pour piano de Liszt: Influence du programme sur l'évolution des formes instrumentales B(udapest: MTA Zenetudományi Intézet).

Grabócz, Márta (2009) Musique, narrativité, signification (Paris: L'Harmattan).

Hamburger, Klára (2010) Liszt Ferenc zenéje (Budapest: Balassi).

Hamilton, Kenneth (2005) 'Liszt's early and Weimar piano works' in Kenneth Hamilton (ed.) The Cambridge Companion to Liszt (Cambridge University Press), 57-85.

Lamartine [Alphonse de] (1977) OEuvres poétiques. Édition présentée, établie et annotée par Marius-François Guyard (Paris: Gallimard (Bibliothèque de la Pléiade)).

Langer, Susan K. (1953) Feeling and Form: A Theory of Art (New York: Scribner's).

Le Diagon-Jacquin, Laurence (2009) La musique de Liszt et les arts visuels: Essai d'analyse comparée d'après Panofsky illustrée d'exemples, Sposalizio, Totentanz, Von der Wiege bis zum Grabe (Paris: Hermann).

Liszt, Franz (1966) Briefe aus ungarischen Sammlungen 1835-1886. Gesammelt und erläutert von Margit Prahács (Budapest: Akadémiai Kiadó).

Liszt, Ferenc (1989) Válogatott levelei. Ifjúság - virtuóz évek - Weimar (1824-1861). Válogatta, fordította és jegyzetekkel ellátta Eckhardt Mária (Budapest: Zenemükiadó).

Ost, François (2009) Traduire: Défense et illustration du multilingualisme (Paris: Fayard).

Rehding, Alexander (2000) 'Liszt und die Suche nach dem “Tristan”-Akkord' Acta Musicologica, Vol. 72, No. 2, 169-88.

Rehding, Alexander (2005) 'Inventing Liszt's life' in Kenneth Hamilton (ed.) The Cambridge Companion to Liszt (Cambridge: Cambridge University Press), 14-27.

Saffle, Michael (2002) 'Orchestral Works' in Arnold, Ben (ed.) The Liszt Companion (Westport, CT - London: Greenwood Press), 235-79.

Schoenberg, Arnold (1984) Style and Idea. Edited by Leonard Stein (Berkeley and Los Angeles: University of California Press).

Senancour [Étienne Pivert de) (1999) Obermann. Édition présentée et annotée par Jeanne-Maurice Monnoyer (Paris: Gallimard) (Folio).

Somssich, Andor, Ifj. (1925) Liszt Ferenc élete (Budapest: Magyar Irodalmi Társaság). 
Spender, Stephen and Donald Hall (eds.) (1963) The Concise Encyclopedia of English and American Poets and Poetry (London: Hutchinson \& Co.).

Szabolcsi, Bence (1956) Liszt Ferenc estéje (Budapest: Zenemükiadó).

Wagner, Richard (1976) Mein Leben. Vollständige, kommentierte Ausgabe. Herausgegeben von Martin Gregor-Dellin (München: List).

Taruskin, Richard (2005) The Oxford History of Western Music (Oxford - New York: Oxford University Press).

Wagner, Richard (1888) 'Über Frank Liszt’s Symphonische Dichtungen’ in Gesammelte Schriften und Dichtungen. Zweite Auflage. Fünfter Band (Leipzig: E. W. Fritzsch), 182-98.

Walker, Alan (1970) Franz Liszt: The Man and His Music (London: Barrie \& Jenkins).

Walker, Alan (1983) Franz Liszt. Volume One: The Virtuoso Years 1811-1847 (New York: Alfred A. Knopf).

Walker, Alan (1989) Franz Liszt. Volume Two: The Weimar Years 1848-1861 (London: Faber and Faber).

Walker, Alan (1997) Franz Liszt. Volume Three: The Final Years 1861-1986 (Ithaca, NY: Cornell University Press).

Wendland, Kirstin (2002) 'Secular Choral Works' in Ben Arnold (ed.) The Liszt Companion (Westport, CT - London: Greenwood Press), 365-401.

Wuthenow, Ralph-Rainer (ed.) (1970) Gedichte 1830-1900 (München: Deutscher Taschenbuch Verlag). 